\title{
TECHNOLOGY OF FREE CHROME TANNING PROCESS: OPTIMAL LEVEL OF FORMALDEHYDE AS TANNING AGENT FOR MONDOL STINGRAY (Himantura gerrardi)
}

\author{
Laili RACHMAWATI*, Emiliana ANGgRIYANI, Nur Mutia ROSIATI \\ Department of Leather Processing Technology, Politeknik ATK Yogyakarta, Sewon, Bantul, 55281, D.I. Yogyakarta, \\ Indonesia, lailirachma@gmail.com
}

Received: 07.10.2019

Accepted: 01.07.2020

https://doi.org/10.24264/Ifj.20.3.6

TECHNOLOGY OF FREE CHROME TANNING PROCESS: OPTIMAL LEVEL OF FORMALDEHYDE AS TANNING AGENT FOR MONDOL STINGRAY (Himantura gerrardi)

ABSTRACT. Chrome (VI) has a high level of toxicity. Formaldehyde is potential to be developed as a substitute of chrome tanning agent. The aims of this study are to explain the amount of formaldehyde bound, shrinkage temperature, tensile strength, and tear strength on Mondol stingray (Himantura gerrardi) leather. Pickled mondol stingray has been used as raw material. The study was divided into 4 treatments, that is P.I (formaldehyde $2 \%$ ), P.II (formaldehyde 4\%), P.III (formaldehyde 6\%), and P.IV (formaldehyde $8 \%$ ). The method used is drum tanning. Shrinkage temperatures, tensile strength and tear strength of P.I and P.II are significantly different from P.III and P.IV, but P.I is not significantly different from P.II, whereas P.III is not significantly different from P.IV. P.III is shown to improve the quality of leather stingray more than P.I and P.II, and has fulfilled the requirements of leather stingray according to SNI. 06-6121-1999. It can be concluded that the optimal level of formaldehyde tanning agent that can be used as a chrome tanning agent substitute in tanning Mondol stingray skin is formaldehyde $8 \%$ (P.III). KEY WORDS: free chrome tanning agent, formaldehyde, Himantura gerrardi

\section{TEHNOLOGIA PROCESULUI DE TĂBĂCIRE FĂRĂ CROM: NIVELUL OPTIM DE FORMALDEHIDĂ UTILIZATĂ CA AGENT DE TĂBĂCIRE PENTRU PIELEA DE PEȘTE STINGRAY (Himantura gerrardi)}

REZUMAT. Cromul (VI) are un nivel ridicat de toxicitate. Formaldehida are potențial de utilizare ca substitut pentru agentul de tăbăcire pe bază de crom. Scopul acestui studiu este de a determina cantitatea de formaldehidă legată, temperatura de contracție, rezistența la rupere și rezistența la sfâșiere a pielii de pește stingray (Himantura gerrardi). Ca materie primă s-a folosit piele de pește stingray piclată. Studiul a fost împărțit în 4 tratamente, și anume: P.I (formaldehidă 2\%), P.II (formaldehidă 4\%), P.III (formaldehidă 6\%) și P.IV (formaldehidă $8 \%$ ). Metoda folosită este tăbăcirea în butoi. Temperaturile de contracție, rezistența la rupere și rezistența la sfâșiere a P.I și P.II sunt semnificativ diferite de P.III și P.IV, dar P.I nu este semnificativ diferit de P.II, în timp ce P.III nu este semnificativ diferit de P.IV. Este cunoscut faptul că P.III îmbunătățește mai mult calitatea pielii de pește decât P.I și P.II și îndeplinește cerințele referitoare la pielea de pește stingray conform SNI. 06-6121-1999. Se poate concluziona că nivelul optim de tăbăcire cu formaldehidă care poate fi utilizată ca substitut pentru agentul de tăbăcire pe bază de crom pentru pielea de pește stingray este de $8 \%$ formaldehidă (P.III).

CUVINTE CHEIE: agent de tăbăcire fără crom, formaldehidă, Himantura gerrardi

\section{TECHNOLOGIE DU PROCESSUS DE TANNAGE SANS CHROME : LE NIVEAU OPTIMAL DE FORMALDÉHYDE COMME AGENT DE TANNAGE} POUR LA PEAU DE RAIE (Himantura gerrardi)

RÉSUMÉ. Le chrome (VI) a un haut niveau de toxicité. Le formaldéhyde est susceptible d'être développé comme substitut de l'agent de tannage au chrome. Les objectifs de cette étude sont de déterminer la quantité de formaldéhyde lié, la température de retrait, la résistance à la traction et la résistance à la déchirure de la peau de raie (Himantura gerrardi). La peau de raie picklée a été utilisée comme matière première. L'étude a été divisée en 4 traitements, à savoir P.I (formaldéhyde 2\%), P.II (formaldéhyde 4\%), P.III (formaldéhyde 6\%) et P.IV (formaldéhyde $8 \%$ ). La méthode utilisée est le tannage au tambour. Les températures de retrait, la résistance à la traction et la résistance à la déchirure de P.I et P.II sont significativement différentes de P.III et P.IV, mais P.I n'est pas significativement différente de P.II, tandis que P.III n'est pas significativement différente de P.IV. II est connu que P.III améliore davantage la qualité des peaux de raie que P.I et P.II, et satisfait les exigences des peaux de raie selon SNI. 06-6121-1999. On peut conclure que le niveau optimal d'agent de tannage au formaldéhyde qui peut être utilisé comme substitut d'agent de tannage au chrome pour la peau de raie est le formaldéhyde à $8 \%$ (P.III).

MOTS CLÉS : agent de tannage sans chrome, formaldéhyde, Himantura gerrardi

\section{INTRODUCTION}

The skin tanning process is a process to convert raw skin into tanned skin or leather [1], this process has a major role in increasing the stability of triple helix structures from the collagen matrix [2]. All skin types can be processed into leather [3]. Fish skin has been widely used as a variety of leather products that have high economic value. The favorite skin type of fish is stingray skin because of its skin structure which has fine stones, resulting in leather with special and exotic features, and can reach widths up to 30 inches [4].

Currently, the leather tanning industry is required to have an eco green technology label [5], which is an environmentally friendly industry. The big challenge facing the leather tanning industry in Indonesia in applying the eco green technology label is the dominance of the use of chrome tanning agents. Chrome is a tanning agent which has very high toxicity, especially in the form of chrome (VI) [6]. Therefore, an

\footnotetext{
* Correspondence to: Emiliana ANGGRIYANI, Department of Leather Processing Technology, Politeknik ATK Yogyakarta, JI. Ringroad Selatan, Glugo, Panggungharjo, Sewon, Bantul, 55281, Yogyakarta, Indonesia, emiliana.anggry@gmail.com
} 
alternative tanning substitute for chrome is needed that is more environmentally friendly.

Some chrome substitute tanning agents have been developed, such as zirconium (VI) and aluminum (III) that have high durability and water resistance. Besides, there are also phosphonium, several types of syntans, and aldehydes that are more environmentally friendly and have biodegradable properties [7]. One type of aldehyde that has the potential to be developed as a chrome substitute tanning agent is formaldehyde. Formaldehyde tanning from formalin has been widely used in the leather tanning industry especially for wet white leather [8]. Formaldehyde tanning agents can easily bind to skin collagen, by forming strong complexes so that the skin becomes denser [9]. The use of chromium-formaldehyde combination tanning agents provides good effects on tensile strength, tear strength and thickness [10].

Formaldehyde has applications in many industrial processes [11], and it still permitted to be used as tanning material with a limit to the number identified in leather, where in each country has different limits [12]. Maximum formaldehyde limits detected in tanned skin for adults and direct contact with skin is $75 \mathrm{mg} /$ $\mathrm{kg}$, for tanned skin that is not in direct contact with the skin is $300 \mathrm{mg} / \mathrm{kg}$, while for tanned skin which is intended for children is of maximum 20 $\mathrm{mg} / \mathrm{kg}$ [13].

Some leather tanning companies have used formaldehyde as a tanning agent, with a concentration of $8-10 \%$ formalin use [3], so research that examines the optimal level of use of formaldehyde tanning agents on stingray skin so that formaldehyde use can be controlled. Therefore, this study aims to explain the amount of formaldehyde that can be bound to the skin of the mondola stingray (Himantura gerrardi) and the shrinkage temperature, tensile strength, and shrinkage strength that can be achieved by using formaldehyde tanning agents. Then, the results are compared with the Indonesian standards for fish skin leather (SNI. 06-6121-1999).

\section{EXPERIMENTAL}

\section{Materials and Methods}

\section{Instruments}

Thermometer, pH indicators, BCG indicators, small cutting knives, bucket, and process drums (RPM: 10-12).

\section{Materials}

40 sheets of pickled stingray skin, $\mathrm{H}_{2} \mathrm{O}$, $\mathrm{NaCl}, \mathrm{MgO}, \mathrm{NaHCO}_{3}$, and formalin (with $80 \%$ formaldehyde level).

\section{Tanning Process}

This study was divided into 4 treatments: treatment I ( $2 \%$ formaldehyde), treatment II (formaldehyde 4\%), treatment III (formaldehyde $6 \%$ ), and treatment IV (8\% formaldehyde). Each treatment consisted of 10 sheets of stingray skin. The pre-tanning process flow is shown in Figure 1. The tanning method uses drum tanning and formulation refers to [3] shown in Table 1. 


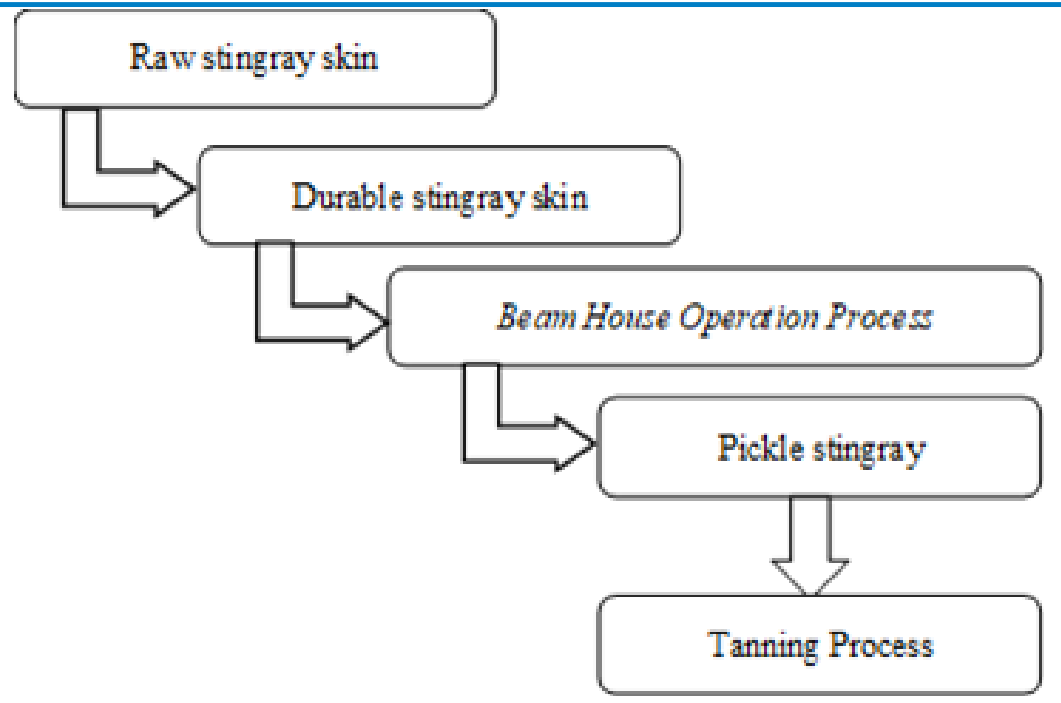

Figure 1. Scheme of pre-tanning process

Table 1: Formulation of the formaldehyde tanning process

\begin{tabular}{|c|c|c|c|c|c|}
\hline \multirow[t]{2}{*}{ Process } & \multirow[t]{2}{*}{$\%$} & \multirow[t]{2}{*}{ Chemicals } & \multicolumn{3}{|c|}{ Control } \\
\hline & & & $\begin{array}{c}\text { Time } \\
\text { (minutes) }\end{array}$ & $\mathrm{pH}$ & $\begin{array}{c}\text { Temperature } \\
\left({ }^{\circ} \mathrm{C}\right)\end{array}$ \\
\hline \multirow[t]{5}{*}{ Tanning } & 75 & $\mathrm{H}_{2} \mathrm{O}$ & & & \\
\hline & 10 & $\mathrm{NaCl}$ & & & \\
\hline & P.I; P.II; P.III; P.IV & Formalin & $150^{\prime}$ & & $32^{\circ} \mathrm{C}$ \\
\hline & 1 & $\mathrm{MgO}$ & & & \\
\hline & 0,25 & $\mathrm{NaHCO}_{3}$ & $15^{\prime}$ & 7 & \\
\hline \multirow[t]{2}{*}{ Washing } & 0,5 & $\mathrm{NaHSO}_{3}$ & $30^{\prime}$ & & \\
\hline & 2 & $\mathrm{H}_{2} \mathrm{O}_{2}$ & $10^{\prime}$ & 6,5 & \\
\hline \multicolumn{6}{|l|}{ Drain } \\
\hline Drying & & & & & \\
\hline
\end{tabular}

\section{Data Analysis}

The data obtained were analyzed using SPSS version 17.0 for Windows [14]. The analysis used is the compare means analysis (One Way ANOVA) to compare each treatment with significant value is $\mathrm{P}<0,05$ [15]. Further results from wet blue stingray skin were analyzed using FTIR (Fourier Transmitted Infra Red).

\section{RESULTS AND DICUSSION}

\section{Formaldehyde Levels}

Based on the results of the analysis of formaldehyde, the levels of bound formaldehyde and free formaldehyde of stingray skin for each treatment are known (Table 2).

Table 2: Levels of formaldehyde bound

\begin{tabular}{ccc}
\hline \% Use of formaldehyde & Bound formaldehyde $(\mathrm{mg} / \mathrm{kg})$ & Free formaldehyde $(\mathrm{mg} / \mathrm{kg})$ \\
\hline 2 & 2136.67 & 0.32 \\
4 & 2433.33 & 0.40 \\
6 & 1933.33 & 0.27 \\
8 & 2833.33 & 0.20 \\
\hline
\end{tabular}


The results obtained showed that each treatment gave different results in \% formaldehyde bound. The highest level of formaldehyde bound was $8 \%$ in formaldehyde use, the skin was able to bind the aldehyde as much as $2833.3 \mathrm{mg} / \mathrm{kg}$. This shows that commonly the more formaldehyde used, the more the amount of the aldehyde will bind to the skin amine group. The most dominant reaction between formaldehyde and skin protein is the skin amine group from the amino acid lysine. The reaction between amines and formaldehyde forms a formation called methylol derivatives [16]. Aldehydes can further react with tannins from vegetable tanning agents, then form vegetable tannins to form cross-bonds with skin collagen when there are high-activity nucleophilic sites in tannin molecules [17].
Besides formaldehyde bound, the analysis of free formaldehyde was also carried out. It was known that the highest level of free formaldehyde was reached at $4 \%$ use of formaldehyde. This shows that at this level of use, the skin is able to bind a great level of formaldehyde but it also releases quite a lot of formaldehyde. The lowest level of free formaldehyde was found in $8 \%$ use of formaldehyde. This clarifies that the use of $8 \%$ formaldehyde in tanning of stingray skin yields the leather with the highest of formaldehyde bound and the lowest of free formaldehyde.

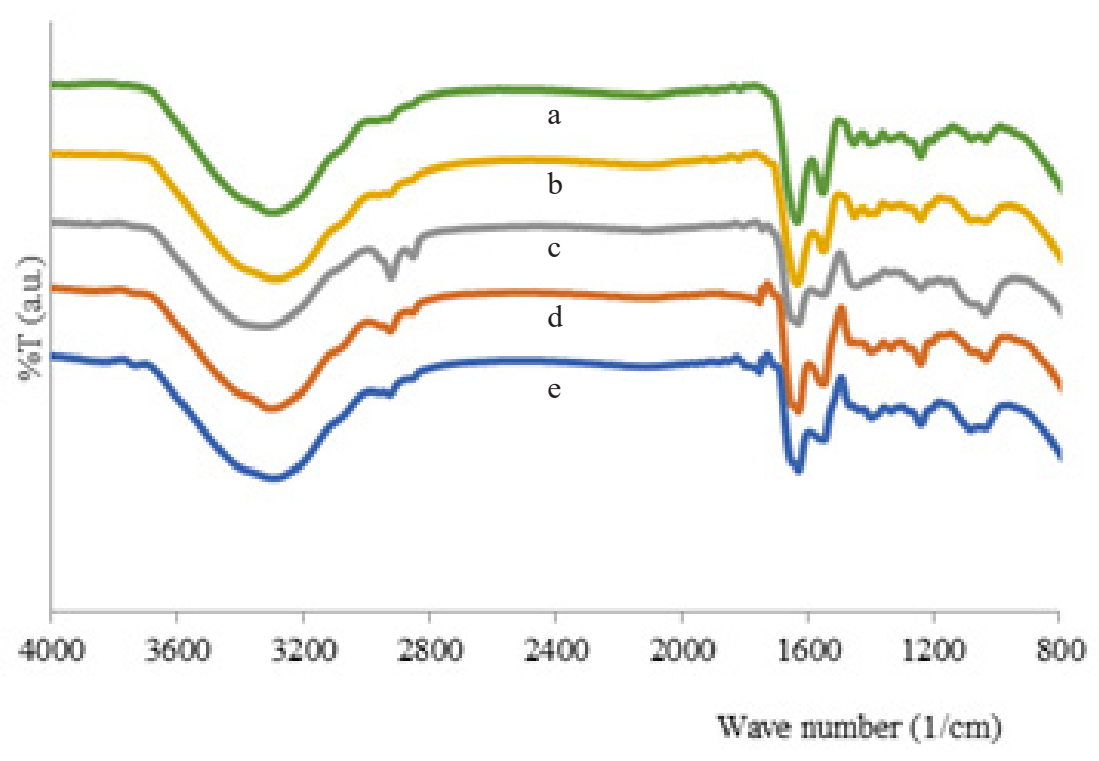

Figure 2. Infrared spectra: (a) shell skin; formaldehyde leather (b) 2\%; (c) 4\%; (d) 6\%; (e) $8 \%$

Analysis of sample FTIR uptake is shown in Figure 2. Pellicle has several characteristic absorption bands. The absorption band at wave number $1035 \mathrm{~cm}^{-1}$ appears as a bending vibration of the aromatic group of vegetable tanning agents [18]. The presence of a methylene group $\left(-\mathrm{CH}_{2}{ }^{-}\right)$ in skin collagen was identified at wave numbers 1339 and $1452 \mathrm{~cm}^{-1}$ as wagging vibrations and bending vibrations. Vibration of the $-\mathrm{NH}$ group from amide III resulted in absorption at the wave number region $1241 \mathrm{~cm}^{-1}[19,20]$. Uptake at wave number $1553 \mathrm{~cm}^{-1}$ is a bending vibration
$-\mathrm{NH}_{2}$ and a stretching vibration of $\mathrm{CN}$ in amide group II. The uptake of the amide group I is seen in the wave number region $1630 \mathrm{~cm}^{-1}$ as stretching vibration $C=0$ [21]. The binding of $\mathrm{N}-\mathrm{H}$ to amino acid groups results in uptake in the area of $3300 \mathrm{~cm}^{-1}$ [18].

The success of the tanning process of stingray skin with formalin is proven through infrared absorption analysis. If viewed from its absorption of infrared radiation, there was no significant change between the pellet skin absorption band with formalin tanned skin. This 
is due to the type of bond that is formed is not too different between the skin of the particles with formalin tanned leather. The mechanism of the reaction that occurs is shown in Figure 3. Based on the reaction it is known that the tanning process produces a Schiff base. The $\mathrm{C}$ $=\mathrm{N}$ bond on formalin tanned skin was detected through absorption bands at the wave number region 1547-1551 $\mathrm{cm}^{-1}$ [22]. This absorption band overlaps with bending vibrations $-\mathrm{NH}_{2}$ and $\mathrm{CN}$ stretching vibrations on amide II groups of proteins [20]. Uptake of the $\mathrm{CH}$ bond causes the appearance of absorption bands at the wave number region $1440-1450 \mathrm{~cm}^{-1}$ as stretching vibrations of the groups $-\mathrm{CH}_{2}-$ and 2853-2927 $\mathrm{cm}^{-1}$ as stretching vibrations of $\mathrm{C}-\mathrm{H}$ asymmetry [22]. Vibration of $\mathrm{N}-\mathrm{H}$ from amino acid groups was detected in regions of $3300 \mathrm{~cm}^{-1}$ [9]. The difference in the concentration of formalin used in the tanning process was not observed significantly in the infrared absorption band. This shows that there are no differences in the types of bonds formed due to various concentrations.<smiles>O=CCCNP</smiles><smiles>[2H][NH+]([3H])CCC=C</smiles><smiles>C=CCOC</smiles><smiles>C=NP</smiles><smiles>OCC(O)C1CN1P</smiles>

Figure 3. The mechanism of the reaction between the skin of the particles and formaldehyde $(P=$ protein)

Formalin on the market generally contains $80 \%$ formaldehyde and has the chemical formula $\mathrm{H}_{2} \mathrm{CO}_{3}$ [23]. Formaldehyde can react with the functional group $-\mathrm{NH}_{2}$ perfectly so that it can change the physical properties of collagen proteins.

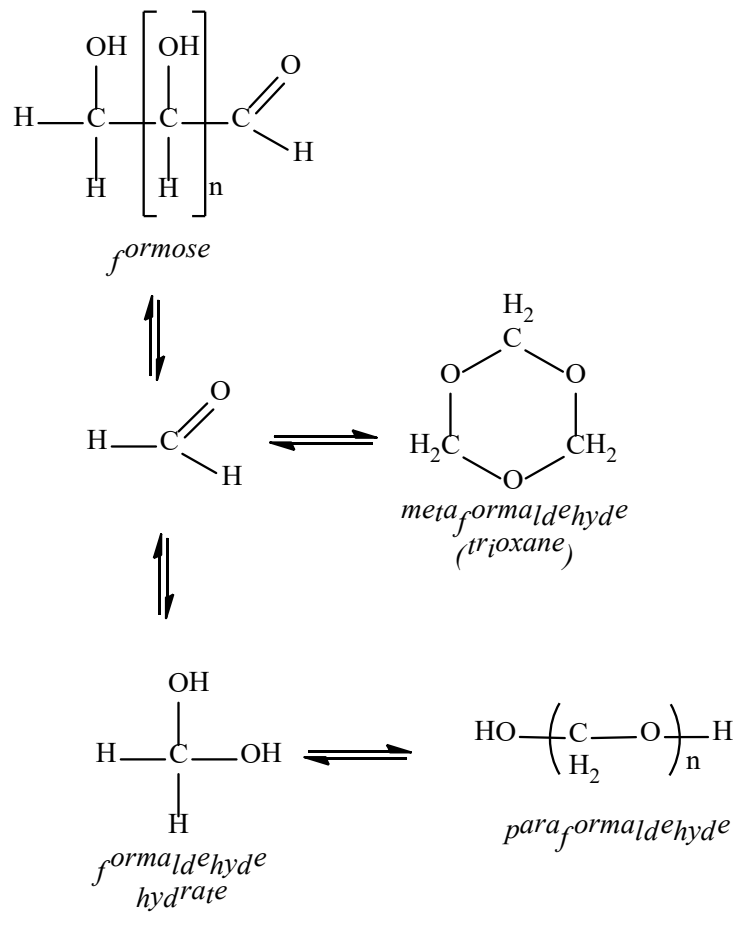

Figure 4. Structure of formaldehyde [5] 
Formaldehyde is an aldehyde tanning agent with a simple structure that has 1 aldehyde group [16]. The chemical structure of formaldehyde is shown in Figure 4. Formaldehyde can be found in the polymerized form depending on the type of sample used. In addition, formaldehyde can be in the form of hydration, but generally formaldehyde species are dominated by paraformaldehyde [24]. The presence of a hydroxyl group (-OH) in formaldehyde causes tanned skin to have hydrophilic properties, so it is often used for gloves articles. Hydrophilic properties are the effects of the polymeric properties of tanning substances, which encourage separate fiber structures, and the presence of hydrogen bonding groups in polymers.

Some studies show formaldehyde reactions using NMR spectroscopy. The reaction with gelatin shows that lysine is a group favored by the aldehyde then arginine.
Unexpected modifications are found in peptides containing free $\mathrm{N}$-terminal amino groups or arginine residues. Adduction of formaldehyde reacts with the $\mathrm{N}$ tip through two steps: the $\mathrm{N}$ tip forms imidazolidinone, and then glycine is attached via the methylene bridge. Two covalent modifications occur in arginine-containing peptides: (i) attachment of one glycine molecule to arginine residue through two methylene bridges, and (ii) merging two glycine molecules through four methylene bridges. It is known that formaldehyde does not produce crosslinking between molecules between two primary amino groups [25].

\section{Shrinkage Temperature}

Table 3 presents the results of observations on increasing the shrinkage temperature of the results of stingray skin tanning.

Table 3: Temperature shrinkage of Mondol stingray skin (Himantura gerrardi)

\begin{tabular}{cc}
\hline \% Use of formaldehyde & Shrinkage temperature $\left({ }^{\circ} \mathrm{C}\right)$ \\
\hline 2 & $63.041 \pm 0.107^{\mathrm{a}}$ \\
4 & $66.050 \pm 0.100^{\mathrm{a}}$ \\
6 & $76.750 \pm 1.405^{\mathrm{b}}$ \\
8 & $77.333 \pm 1.505^{\mathrm{b}}$ \\
\hline a and b show real differences $(\mathrm{p}<0,05)$
\end{tabular}

Shrinkage temperature is the temperature of the skin when the collagen structure shrinks by heating in a water medium or the point where the skin of the host begins to shrink at a certain temperature. This shrinkage occurs because the folds of the polypeptide chain due to the strength of the woven collagen fibers break up by extreme conditions such as heating at high temperatures [10]. The skin consists of a bundle of three-dimensional collagen fibers, and the main component of skin forming is collagen which is a well-structured fibrous protein. Skin tanning plays a major role in increasing the stability of the helical triple structure of the collagen matrix. The tanning material has varied efficiency in the stability of collagen. Thermal stability of leather is known from conventional shrinking test (CST) method and differential scanning calorimetry (DSC) method [2]. The standard shrinkage temperature used in this study is the temperature when the sample begins to experience $150 \mu \mathrm{m}$ shrinkage [26].
Based on the results in Table 3, it is known that the use of formaldehyde with levels of $2 \%$ and $4 \%$ produces tanned skin with a shrinkage temperature $\left({ }^{\circ} \mathrm{C}\right)$ that is significantly different $(P<0.05)$ compared to formaldehyde use of $6 \%$ and $8 \%$. The more amount of formaldehyde used increases the shrinkage temperature $\left({ }^{\circ} \mathrm{C}\right)$ of tanned stingray skin. The use of 2 and $4 \%$ formaldehyde tanning agents has not been able to increase the shrinkage temperature to 70 ${ }^{\circ} \mathrm{C}$ on stingray skin, while the use of 6 and $8 \%$ have been able to give the effect of increasing the shrinkage temperature to more than 70 ${ }^{\circ} \mathrm{C}$. This is possible because the more amount of formaldehyde is used, the higher the bond between the aldehyde and the skin amine group, so that the shrinkage temperature rises.

The tanning treatment using formaldehyde at $6 \%$ and $8 \%$ have met the SNI 06-02341990 standard, namely, the minimum wrinkle temperature that must be achieved by stingray skin for leather goods is $70{ }^{\circ} \mathrm{C}$. It was known 
that the shrinkage temperature achieved in $6 \%$ formaldehyde use was able to increase the shrinkage temperature of tanned fish skin to $76.750 \pm 1.405{ }^{\circ} \mathrm{C}$, the results were not significantly different $(P<0.05)$ with $8 \%$ formaldehyde use which was able to increase shrinkage temperatures to $77.333 \pm 1.505{ }^{\circ} \mathrm{C}$. This shows that the use of $6 \%$ formaldehyde has been optimal for increasing the shrinkage temperature of tanned fish skin, because it gives results that are not significantly different from the use of $8 \%$ formaldehyde. Although the tanning material still provides a lower shrinkage temperature than the chrome tanner, formaldehyde has been able to give an effect of increasing shrinkage temperature according to $\mathrm{SNI}$, which is at least $70^{\circ} \mathrm{C}$.

It is difficult for formaldehyde to form cross bonds with amino acid groups rather than chrome, so the shrinkage temperature achieved is not as high as when using chrome tanning material [24]. Several studies have stated that the maximum shrinkage temperature that can be achieved with formaldehyde tanning agents is $80^{\circ} \mathrm{C}$.

Formaldehyde also has a lower shrinkage temperature when compared with glutaraldehyde [27]. D-Lysine uptake is found more when the use of glutaraldehyde is increased in tanning. The amino groups both lysine and hydroxyproline are involved in the glutaraldehyde tanning reaction. It is possible that D-Lysine has improved hydrothermal stability. Increased shrinkage temperature showed increased stability of wet white skin [5].

\section{Tensile Strength}

Tensile strength is the amount of load needed to pull tanned fish skin $\left(\mathrm{N} / \mathrm{cm}^{2}\right)$ until the collagen fibers are cut off, this study produced the tensile strength presented in Table 4.

Table 4: Tensile strength of Mondol stingray skin (Himantura gerrardi)

\begin{tabular}{cc}
\hline \% Use of formaldehyde & Tensile strength $\left(\mathrm{N} / \mathrm{cm}^{2}\right)$ \\
\hline 2 & $2084.803 \pm 14.974^{\mathrm{a}}$ \\
4 & $2093.982 \pm 9.858^{\mathrm{a}}$ \\
6 & $2533.022 \pm 2.027^{\mathrm{b}}$ \\
8 & $2564.758 \pm 32.757^{\mathrm{b}}$ \\
\hline a and b show real differences $(\mathrm{p}<0,05)$
\end{tabular}

Based on the test results presented in Table 4, the concentration of formaldehyde use of 2 and $4 \%$ gave the value of tensile strength of tanned stingray skin at 2.084.803 \pm 14.974 $\mathrm{N} / \mathrm{cm}^{2}$ and $2.093 .982 \pm 9.858 \mathrm{~N} / \mathrm{cm}^{2}$, these results were significantly different $(P<0.05)$ with formaldehyde use of 6 and $8 \%$, which are $2.533 .022 \pm 2.027 \mathrm{~N} / \mathrm{cm}^{2}$ and 2.564.758 \pm 32.757 $\mathrm{N} / \mathrm{cm}^{2}$. The tensile strength of tanned stingray skin in this experiment shows a value that tends to increase in line with the increase in the concentration of formaldehyde tanning agent. All treatments provide tensile strength values that meet the SNI 06-6121-1999 standard for tanned stingray skin, which is a minimum of $2.000 \mathrm{~N} /$ $\mathrm{cm}^{2}$. Every tanned skin must meet the minimum SNI value because it becomes a benchmark for the manufacture of leather products [27].

Goat skin tanned with aldehyde tanner produces higher tensile strength than those tanned with chrome [28]. When viewed from the level of density, this can be caused because formaldehyde tanned leather has a higher density level than chrome tanned leather, but has a lower elongation [10]. The use of non-formaldehyde melamine resin as a retanning agent has the effect of increasing the attractiveness of the nail than formaldehyde melamine resin [29].

The main tensile strength of tanned skin is influenced by the size of fibril diameter and collagen fibers, therefore the skin that comes from older animals tends to have higher tensile strength than young animal skin because collagen fibers become increasingly stable [30]. Mondol stingray skin tanned by formalin with a concentration of $8 \%$ had a tensile strength of 2,397.85 $\left(\mathrm{N} / \mathrm{cm}^{2}\right)$ [10], this result was lower than that reported in this study, however, the two results of this study had met SNI standards about tanned stingray skin. This is probably due 
to the differences in the age of stingrays used as samples in the study so that it is necessary to further study the effect of age on the tensile strength of stingray skin.

\section{Tear Strength}

Tearing strength is an important factor in determining skin quality because it shows that the maximum limit of the skin can be torn [31]. The results obtained from testing the strength of the rays of stingray skin tanned using formaldehyde tanners with different concentrations are shown in Table 5.

Table 5: Tear strength of Mondol stingray skin (Himantura gerrardi)

\begin{tabular}{cc}
\hline$\%$ Use of formaldehyde & Tear strength $(\mathrm{N} / \mathrm{cm})$ \\
\hline 2 & $447.174 \pm 1.486^{\mathrm{a}}$ \\
4 & $457.790 \pm 2.998^{\mathrm{a}}$ \\
6 & $627.771 \pm 0.358^{\mathrm{b}}$ \\
8 & $610.687 \pm 2.489^{\mathrm{b}}$ \\
\hline a and b show real differences $(\mathrm{p}<0,05)$
\end{tabular}

The use of 2 and $4 \%$ formaldehyde tanners produced a tear strength of $447.174 \pm 1.486 \mathrm{~N} /$ $\mathrm{cm}$ and $457.790 \pm 2.998 \mathrm{~N} / \mathrm{cm}$, these results were lower than the strength of the rind skin which was tanned with formaldehyde 6 and $8 \%$ namely $627.771 \pm 0.358 \mathrm{~N} / \mathrm{cm}$ and $610.687 \pm 2.489 \mathrm{~N} /$ $\mathrm{cm}$ with values that have met SNI 06-6121-1999 (minimum $300 \mathrm{~N} / \mathrm{cm}$ ). This study showed that the stingray skin was tanned with a tendency of tear strength to increase in line with the increase in the concentration of formaldehyde tanning agent.

Based on the above results it is known that the increase in the concentration of $4 \%$ formaldehyde to $6 \%$ formaldehyde had a significantly different effect, and did not differ when the formaldehyde concentration was increased to $8 \%$. This shows that $6 \%$ formaldehyde concentration has been able to produce tear strength with a value similar to $8 \%$ formaldehyde, even in the use of $8 \%$ formalin gave a lower tear strength value of $371.52 \pm 2.10$ $\mathrm{N} / \mathrm{cm}$ [10]. Therefore, it can be suggested that the level of use of formaldehyde used in several tanning industries will be reduced.

In addition to producing tanned leather which has a shrinkage temperature, tensile strength and strong tear that meets the SNI 066121-1999 standard, tanning with formaldehyde produces tanned white leather so that it is suitable for use in articles of natural color leather products. Some industries have applied tanning with formaldehyde tanners especially for woolskin and gloves articles with high sweat resistance [27].

Even though until now, chrome is still considered a "perfect" tanning agent to produce the desired tanned skin, but the use of tanning material must be stopped immediately because of its impact on health and the environment. Several studies have examined alternative tanning substitutes, including iron, aluminium, titanium, zirconium, polyphenols, polymers, aldehydes, carbohydrates. Therefore, this study has examined the optimal levels of formaldehyde use as an alternative tanner substitute for chrome.

Formalin is still freely used in the leather tanning industry; it is important to remember that formalin is a type of toxic and dangerous material. Formalin is known to interfere with the respiratory tract [32]. The glutaraldehyde aldehyde has a high level of toxicity indicated by inhibition of the growth of Aspergillus niger sp. [33]. Therefore, the use of formaldehyde needs to be limited including in the leather tanning industry, one of which is the determination of the maximum amount of formalin use as tanning material.

\section{CONCLUSIONS}

Formaldehyde tanning agent can be used to replace chrome. Optimal level of use of formaldehyde tanning agent is $8 \%$, it can reach shrinkage temperatures, tensile strength 
and tear strength that have met the minimum standards set by SNI. 06-6121-1999.

\section{REFERENCES}

1. Erlita, Y., The Tanning Process (Proses Penyamakan Kulit). Dinas Peternakan dan Kesehatan Hewan, Provinsi Sumatra Barat, 2016.

2. Onem, E., Yorgancioglu, A., Karavana, H.A., Yilmaz, O., Comparison of Different Tanning Agents on The Stabilization of Collagen Via Differential Scanning Calorimetry, J Therm Anal Calorim, 2017, 129, 1, 615-622, https:// doi.org/10.1007/s10973-017-6175-x.

3. Purnomo, E., Mineral Tanning Techniques (Teknik Penyamakan Mineral), Depatment of Teknologi Pengolahan Kulit, Polytechnic ATK Yogyakarta, Yogyakarta, 2017.

4. Sahubawa, L., Pertiwiningrum, A., Lelana, I.Y.B., Meylinda, Increased Economic Value of Tanned Stingray Skin Waste (Peningkatan Nilai Ekonomi Limbah Kulit Ikan Pari Tersamak), Prossiding Hasil-hasil Penelitian Perikanan dan kelautan VII, 2010, Jurusan Perikanan, Fakultas Pertanian UGM, Yogyakarta.

5. Krishnamoorthy, G., Sadulla, S., Sehgal, P.K., Mandal, A.B, Greener Approach to Leather Tanning Process: D-Lysine Aldehyde as Novel Tanning agent for Chrome-Free Tanning, J Clean Prod, 2013, 42, 277-286, https://doi. org/10.1016/j.jclepro.2012.11.004.

6. U.S. Department of Health and Human Services, Toxicological Profile for Chromium, Agency for Toxic Sustances and Disease Registry, Devision of Toxicology and Human Health Sciences, Environmental Toxicology Branch, Atlanta, Georgia, 2012, 11-12.

7. Basaran, B., Sancakli, A., Dilek, Y., Improving The Properties of Wet-white Yanned Leather Characteristics by Using Collagen-based Biopolymer, XXXIII IULTCS Congress, Novo Hamburgo, Brazil, November 2015, 1-10.

8. Purnomo, E., Abdullah, S.S., Rachmawati, L., Fish Skin Post Tanning Techniques (Teknik Pasca Tanning Kulit Ikan), Depatment of Teknologi Pengolahan Kulit, Polytechnic ATK Yogyakarta, Yogyakarta, 2018.

9. Astrida, M., Sahubawa, L., Ustadi, The Effect of Tanning Material on The Quality of Parrot Fish Tanned (Pengaruh jenis bahan penyamak terhadap kualitas kulit ikan nila tersamak), Jurnal Perikanan dan IImu Kelautan, 2008, 1, 1, 100-110.

10. Kusmaryanti, T., Ibrahim, R., Riyadi, P.H., The Effect of Different Tanning Materials towards Leather Quality of Tanned Mondol Stingray (Pengaruh Perbedaan Bahan Penyamak Terhadap Kualitas Kulit Ikan Pari Mondol (Himantura gerrardi) Tersamak), Indonesian Journal of Fisheries Science and Technology, 2016, 11, 2, 140-147, https:// doi.org/10.14710/ijfst.11.2.140-147.

11. Marsal, A., Cuadros, S., Manich, A.M., Izquierdo, F., Font, J., Reduction of The Formaldehyde Content in Leathers Treated with Formaldehyde Resins by Means of Plant Polyphenols, J Clean Prod, 2017, 148, 518-526, https://doi.org/10.1016/j. jclepro.2017.02.007.

12. Federation of Indian Micro and Small \& Medium Enterprises (FISME), Handbook on Mandatory and Voluntary Standards on Leather and Footwear Products, New Dehli, 2007.

13. Levi strauss \& co, Restricted Substances List, California, 2010.

14. $\mathrm{IBM}^{\circledast}$, SPSS Statistics Editions, IBM Corporation Software Group, United States of America, 2009.

15. Astuti, M., Introduction to Statistics for Animal Husbandry and Animal Health (Pengantar Ilmu Statistik untuk Peternakan dan Kesehatan Hewan), Binasti Publisher, Bogor, 2007, 47-48.

16. Thorstensen, T.C., Practical Leather Technology, Ed. 4th, Krieger Publishing Company, Florida, 1993, 182-183.

17. Lu, Z., Liao, X.P., Shi, B., The Reaction of Vegetable Tannin-Aldehyde-Collagen: A Futher Understanding of Vegetable TanninAldehyde Combination Tannage, J Soc Leath Tech Ch, 2003, 87, 5, 173-178.

18. Hedberg, Y.S., Lidén, C., Wallinder, I.O., Correlation between Bulk- and Surface Chemistry of Cr-Tanned Leather and the Release of $\mathrm{Cr}(\mathrm{III})$ and $\mathrm{Cr}(\mathrm{VI})$, J Hazard Mater, 2014, 280, 654-661, https://doi. org/10.1016/j.jhazmat.2014.08.061.

19. Nashy, E.H.A., Osman, O., Mahmoud, A.A., Ibrahim, M., Molecular Spectroscopic Study for Suggested Mechanism of Chrome Tanned Leather, Spectrochim Acta A, 2012, 
88, 171-176, https://doi.org/10.1016/j. saa.2011.12.024.

20. Banarjee, P., Madhu, S., Babu, N.K.C., and Shanthi, C., Bio-mimetic Mineralization Potential of Collagen Hydrolysate Obtained from Chromium Tanned Leather Waste, Mater Sci Eng C, 2015, 49, 338-347, https:// doi.org/10.1016/j.msec.2015.01.027.

21. Pellegrini, D., Corsi, M., Bonanni, M., Bianchini, R., D'Ulivo, A., Bramanti, E., Study of the Interaction between Collagen and Naturalized and Commercial Dyes by Fourier Transform Infrared Spectroscopy and Thermogravimetric Analysis, Dyes Pigm, 2015, 116, 65-73. https://doi.org/10.1016/j. dyepig.2015.01.012.

22. Nuryono, Rosiati, N.M., Rettob, Suyanta, A.L., Arryanto, Y., Coating of 2-Aminobenzimidazole and 1-(o-Tolyl) Biguanide Functionalized Silicas on Iron Sand Magnetic Material for Sorption of $\left[\mathrm{AuCl}_{4}\right]$ , Indones J Chem, 2019, 19, 2, 395-404, https://doi.org/10.22146/ijc.34653.

23. Untari, S., Application of Tannery Technology for Bag Materials with Fast Tanned System (Penerapan Teknologi Penyamakan Kulit untuk Bahan Tas dengan Sistem Samak Cepat), Research Report, Balai Besar Kulit Karet dan Plastik, Yogyakarta, 1997.

24. Covington, T., Tanning Chemistry: The Science of Leather, RSC Publisher, Cambridge, UK, 2009, 329-331.

25. Metz, B., Kersten, G.F., Hoogerhout, P., Brugghe, H.F., Timmermans, H.A., de Jong, A., Meiring, H., ten Hove J., Hennink, W.E., Crommelin, D.J., Jiskoot, W., Identification of Formaldehyde-Induced Modification in Proteins: Reactions with Model Peptides, J Biol Chem, 2004, 279, 8, 6235, https://doi. org/10.1074/jbc.M310752200.

26. Griyanitasari, G., Pahlawan, I.F., Kasmudjiastuti, E., Thermal Stability of Shoe Upper Leather: Comparison of Chesnut and Quebracho as Vegetable Tanning Agent, Mater Sci Eng, 2018, 432, https://doi. org/10.1088/1757-899X/432/1/012040.

27. Purnomo, E., Aldehyde and Synthetic Tanning Techniques (Teknik Penyamakan Aldehida dan Sintetis), Depatment of Teknologi Pengolahan Kulit, Polytechnic ATK Yogyakarta, Yogyakarta, 2015.
28. Rachmawati, L., Anggriyani, E., The Use of Glutaraldehyde Tanning Materials for Goat Skin Tanning, Buletin Peternakan, 2018, 42, 2, 145-149, https://doi.org/10.21059/ buletinpeternak.v42i2.27721.

29. Saleem, R., Adnan, A., Qureshi, F.A., Synthesis and Application of Formaldehyde Free Melamine Glutaraldehyde Amino Resin as an Effective Retanning Agent, Indian J Chem Technol, 2015, 22, 48-55.

30. Hergiyani, R., Darmanto, Y.S., Purnamayati, L., The Effect of Zirconium Tanning Against on Tensile Strength Test, Strength Test of Tear, Glide Test, and Wrinkle Test in Different Fish Type (Pengaruh Penyamakan Zirconium Terhadap Uji Kekuatan Tarik, Uji Kekuatan Sobek, Uji Kemuluran dan Uji Suhu Kerut pada Berbagai Jenis Kulit Ikan), Indonesian Journal of Fisheries Science and Technology, 2018, 13, 2, 105-110, https:// doi.org/10.14710/ijfst.13.2.105-110.

31. Zulfa, F., Swastawati, F., Wijayanti, I., Effect of "Soga Tingi" (Cerios tagal) as a Tanning Agent on The Physical and Chemical Quality of Milkfish (Chanos chanos forsk) (Pengaruh "Soga Tingi" (Cerios tagal) sebagai Bahan Penyamak terhadap Kualitas Fisik dan Kimia Kulit Ikan Bandeng (Chanos chanos forsk)), Jurnal Pengolahan dan Bioteknologi Hasil Perikanan, 2016, 5, 1, 112-117.

32. Sajiman, Nurhamidi, Mahpolah, Study of Formalin, Borax, Rhodamine B and Methylen Yellow in Food Snacks for School Children in Banjarbaru (Kajian Bahan Berbahaya Formalin, Boraks, Rhodamine B dan Methalyn Yellow pada Pangan Jajanan Anak Sekolah di Banjarbaru), Jurnal Skala Kesehatan, 2015, 6, 1, 26-30, https://doi. org/10.31964/jsk.v6i1.26.

33. Rachmawati, L., Udkhiyati, M., Toxicity Test of Chromium and Glutaraldehyde to Determine Greener Chemical In Tannery Industry, Mater Sci Forum, 2017, 901, 160-165, https://doi.org/10.4028/www. scientific.net/MSF.901.160.

(C) 2020 by the author(s). Published by INCDTPICPI, Bucharest, RO. This is an open access article distributed under the terms and conditions of the Creative Commons Attribution license (http:// creativecommons.org/licenses/by/4.0/). 